\title{
Investigating Revisit Intentions for the Boutique Hotels of Penang-A UNESCO World Heritage Site
}

\author{
Yen-Nee Goh ${ }^{1}$ \\ ${ }^{1}$ Graduate School of Business, Universiti Sains Malaysia, Malaysia \\ Correspondence: Yen-Nee Goh, Graduate School of Business, Universiti Sains Malaysia, 11800, USM, Penang, \\ Malaysia. Tel: 60-4-653-5294. E-mail: yngoh@usm.my
}

\author{
Received: August 18, 2014 Accepted: December 5, 2014 Online Published: January 14, 2015 \\ doi:10.5539/ass.v11n4p126 URL: http://dx.doi.org/10.5539/ass.v11n4p126
}

\begin{abstract}
The growth in the number and variety of boutique hotels in tourist destinations has stimulated a wide range of research studies. Nevertheless, within Malaysia, the area remains under studied. In 2008, George Town, a popular heritage destination in Malaysia, was listed as a UNESCO world heritage site, and since then the number of boutique hotels and tourist arrivals have steadily grown. But, to date, there has been no investigation of the determinants of tourists' revisit intention to boutique hotels. Such a study is timely and needed. Based on the theory of planned behaviour (TPB) as its theoretical foundation, this study investigates the determinants of customers' revisit intention for boutique hotels. The findings from 78 completed questionnaires indicate that attitude, subjective norm and customer satisfaction influence customers' revisit intention. Surprisingly, the effect of perceived behavioural control and overall image upon customer revisit intention was not significant.
\end{abstract}

Keywords: revisit intention, boutique hotels, UNESCO's World Heritage Site, Malaysia

\section{Introduction}

Ever since the city of George Town in Penang was awarded UNESCO World Heritage status in 2008, tourist arrivals have risen sharply. In 2013, passenger traffic through Penang airport increased $15.1 \%$, according to Malaysia Airports Holdings Berhad (2013), with international and domestic arrivals reaching 1.2 million and 1.5 million respectively. Furthermore, in 2014 occupancy rate forecast for boutique heritage hotels in George Town is over $80 \%$, with $70 \%$ of the guests visiting from overseas (The Star Property Online, 2014). With the large influx of tourists to Penang and the increasing occupancy rate at boutique heritage hotels, investigating the determinants of customers' revisit intentions is timely and needed. Boutique hotels are gaining popularity and in number in emerging markets, which has, correspondingly, motivated a rise in the number of studies in this area. For example, Bunchua and Chakpitak (2011) examined the use of marketing information systems in boutique hotels at Chiang Mai, Thailand. They noted that the popularity of boutique hotels contributes to more competition with the conventional hotels in Chiang Mai, creating challenges for the hotel operators. Henderson (2011) also noted the growing popularity of the boutique hotel style with hotel owners, operators and guests in Southeast Asia, especially in heritage areas. Because of its World Heritage status, George Town as the Penang capital is chosen for this research study. Penang, being one of the most visited states in Malaysia, is relevant for this study. George Town, as Penang capital, still retains some of its traditional architecture such as those during the British colonial structures despite experiencing rapid development. With the UNESCO's World Heritage Status obtained in 2008, George Town has witnessed the mushrooming of heritage-house-cum-hotels such as Cheong Fatt Tze Mansion, Yeng Keng hotel, Penaga hotel and so on which are gaining favourable attention from the local and foreigners.

Therefore, this study examines the determinants of customers' revisit intentions for boutique hotels located in George Town, a UNESCO World Heritage site. The author believed that by gaining the understanding on the relative important of each determinant which influences customers' revisit intentions will provide valuable insights and suggestion to owner, managers, and hotel operators to further strengthen and improve services offered in achieving customer satisfaction. Indirectly, it helps to guide the marketers on managing their resources and operation in a timely and efficient way. In brief, this study sheds light on how hotel operators can direct their resources to influence customers' future revisit intention. 


\section{Review of Literature and Hypotheses Development}

\subsection{Boutique Hotels}

Given the increase in the number of boutique hotels in recent years, empirical studies of this hotel type have also gained in popularity. Boutique hotels can be referred to as a unique or special type of accommodation, which feature a particular style of décor, modern, minimalist or heritage, and offer additional lifestyle amenities (Victorino et al., 2005). Besides, according to Mcintosh and Siggs (2005), categorization of a boutique hotel could also be based on pricing, motivation of the host, tenure of business (i.e. age) and so on. One unique characteristic in boutique hotels is the small number of guestrooms, with a typical boutique hotel being less than 100 rooms (Lim \& Endean, 2009). Aggett (2007) described boutique hotels to be modern in design, with less than 100 rooms available, and offering personalized services and facilities which are high tech. Similarly, a boutique hotel could refer to those which do not belong to any part of large hotel chains and design individually with personalized services (Lim \& Endean, 2009). From the variety of definitions, McIntosh and Siggs (2005) created a framework with five essential dimensions for the boutique hotels. The hotels could have a special character; provide personal attention, homely features, and superb services together with valued added experiences. In a similar vein, Horner and Swarbrooke (2005) also highlighted that a boutique hotel could be small in size with personalized services.

\subsection{Attitudes and Revisit Intention}

Intention, described as "a stated likelihood to engage in a behaviour" (Oliver, 1997, p. 28), in the context of hotels, was conceptualised by Lee et al. (2010) as the degree a person plans, or attempt to stay at a boutique hotel when travelling. Sparks (2007), on the other hand, conceptualized intention to visit as the degree to which a person values the experience, has a positive attitude towards the experience, expects family and friends to approve, and if he or she has sufficient resources to undertake the revisit.

One of the key determinants of behavioural intention is attitude. Based on the theory of planned behavior (TPB), Ajzen (1991, p. 188) defined attitude as "the degree to which a person has a favorable or unfavorable evaluation or appraisal of the behavior in question". In this paper, the author argued that customers' positive attitude strengthens their revisit intention. This assumption is based on a large body of supporting. For example, an increase in favourable attitude among the hotel customers contributes to an increase in the likelihood of revisiting a hotel was argued by Han and Kim (2010). Previous empirical findings from Ekinci et al. (2008) also found that consumers' overall attitudes positively affect intention to return to a restaurant or hotel. In terms of green hotels, the important of attitude as a determinant of behavioural intention is well recognized. For instance, Kim and Han (2010) found that attitude has a positive and significant relationship on intention to pay conventional hotel prices at a green hotel. Han et al. (2010) supported that attitude positively affects customers' intention to visit a green hotel. In addition, individuals' attitude toward revisiting a destination also significantly affects revisit intention (Huang \& Hsu, 2009). Lwin and Phau (2013), in determining effective advertising appeals for website of small boutique hotels, found that attitudes towards small boutique hotels have a stronger positive relationship with purchase intention for web sites using emotional appeals in comparison with rational appeals. From these existing findings, the following hypothesis was formed:

H1: Attitude is positively and significantly influences on revisit intention.

\subsection{Subjective Norm and Revisit Intention}

Subjective norm, another determinant influencing customer revisit intention, is defined as "the perceived social pressure to perform or not to perform the behavior" (Ajzen, 1991, p. 188). It describes the probability of whether significant others (such as families and colleagues) would approve or disapprove their behaviour (Han et al., 2010). Subjective norm is also positively and significantly associated with the intention to revisit green hotels noted Han and Kim (2010), who also suggested that subjective norm has the greatest direct effect on intention to revisit compared with attitude and perceived behavioural control, has a positive impact on intention to pay conventional hotel prices (Kim \& Han, 2010) and visit intention (Han et al., 2010). From the literature, this study postulated:

H2: Subjective norm is positively and significantly influences on revisit intention.

\subsection{Perceived Behavioural Control and Revisit Intention}

Ajzen (1991, p. 122) described perceived behavioural control as "the perceived ease or difficulty of performing the behavior". In this study, it refers to a situation when a customer's ability to carry out certain behaviours is limited because of scarce resources, which affects his or her revisit intention. Empirical studies support a positive relationship between perceived behavioural controls with intention to stay at a green hotel (Han et al., 
2010), confirmed that perceived behavioural control positively influences intention to pay conventional hotel prices at green hotels (Kim \& Han, 2010), and that perceived behavioural control has a positive and significant relationship with intention to revisit a green hotel (Han \& Kim, 2010). A similar study by Han et al., (2010) also revealed that perceived behavioural control has a positive and significant influence on intention to stay at a green hotel. Consequently, perceived behavioural control forms the basis of a hypothesis:

H3: Perceived behavioural control is positively and significantly influences on revisit intention.

\subsection{Overall Image and Revisit Intention}

Overall image refers to a customer's overall perception towards a type of hotel, shaped and formed by various information sources together with prior knowledge of the hotel and its attributes (Han et al., 2009; Han \& Kim, 2010). The concept of corporate image is already widely studied and discussed (Han et al., 2009), and Lee et al., (2010) also noted that image is an important consideration in tourism and hospitality research. Existing empirical evidence posits that overall image of a hotel contributes to a more favourable behavioural intention (i.e. revisit intention) (Han \& Kim, 2010; Han et al., 2009; Lee et al., 2010). Overall, the existing literature suggests a positive effect of overall image with revisit intention, and from this the following hypothesis is presented:

H4: Overall image is positively and significantly influences on revisit intention.

\subsection{Customer Satisfaction and Revisit Intention}

A number of tourism and hospitality studies have documented the influenced of customer satisfaction upon behavioural intention. For example, Su and Hsu's (2013) study of heritage tourism showed that tourists' satisfaction influences revisit intention among Chinese tourists. Likewise, Ekinci et al. (2008) found that consumer satisfaction had positive effects on intention to return to a restaurant or hotel, as did Clemens et al. (2011), who confirmed that increased customer satisfaction strengthens the likelihood that a customer would return to a hotel. Moreover, a numerous researchers agree that customer satisfaction is significantly associated with revisit intention (Han \& Back, 2007; Han \& Kim, 2010; Han \& Ryu, 2007; Ryu \& Han, 2010). For example, in a restaurant setting, Han and Ryu (2007) and Ryu and Han (2010) found empirical support for customer satisfaction as a significant predictor of repeat visit intentions. Additionally, empirical studies by Han and Back (2007) and Han and Kim (2010) confirmed that customer satisfaction had a significant effect on repeat visit intention to hotels. Finally, an empirical study by Huang and Hsu (2009) also found that satisfaction had a positive effect on revisit intention. Based on these existing results, this study hypothesised:

H5: Customer satisfaction is positively and significantly influences on revisit intention.

\section{Research Method}

\subsection{Data Collection}

Prior to using questionnaire to collect data, two academic expert and industry practitioner are being interview to comment on the representative and suitability of all the survey questions. Several suggestions are given which leads to some amendments on the structure of the survey questionnaires. The survey was collected between January 2013 and March 2013. Using the drop-off, pick-up method, the researchers visited every boutique hotel to explain the purpose of the survey to the manager and to later collect the responses. This cost effective convenience sampling approach was adopted because of a lack of sampling frames on the total number of tourists visiting boutique hotels in George Town (El-Dief \& Font, 2010). The unit of analysis is the individual customer who stays at a boutique hotel in George Town. Since there is no complete listing of boutique hotels, all 12 boutique hotels listed as located in George Town on the Penang Tourism Website were included. Of the 300 questionnaires distributed to the front office managers of the 12 hotels, only $78(26 \%)$ completed questionnaires were returned. There is an equal distribution between male and female respondents (50\%). About $23.1 \%$ of the respondents are from Malaysia and $64.1 \%$ among the respondents choosing heritage as the main reason for their stay at boutique hotels. A detailed profile of the respondents is presented in Table 1.

Testing and analysing the relationships between the research models variables were achieved with smart partial least squares (PLS) software (Ringle et al., 2005) for a number of reasons. First of all, PLS' ability to handle both reflective and formative factors is widely recognised Chin (1998). Secondly, it offers minimal restriction on the distributional characteristics and sample size (Chin, 1998). Overall, since this is an exploratory study, PLS is considered a better method (Chin, 2000). 
Table 1. Respondents demographics profile

\begin{tabular}{|c|c|c|c|}
\hline Variables & Specific Items & $N$ & Percentage (\%) \\
\hline \multirow[t]{2}{*}{ Gender } & Male & 39 & 50 \\
\hline & Female & 39 & 50 \\
\hline \multirow[t]{5}{*}{ Country of Residence } & Malaysia & 18 & 23.1 \\
\hline & Asia & 24 & 30.8 \\
\hline & Australia & 12 & 15.4 \\
\hline & UK & 9 & 11.5 \\
\hline & Others & 15 & 19.2 \\
\hline \multirow[t]{5}{*}{ Age } & $21-30$ & 22 & 28.2 \\
\hline & $31-40$ & 18 & 23.1 \\
\hline & $41-50$ & 17 & 21.8 \\
\hline & $51-60$ & 12 & 15.4 \\
\hline & More than 60 & 9 & 11.5 \\
\hline \multirow[t]{4}{*}{ Employment Status } & Employed & 51 & 65.4 \\
\hline & Self-Employed & 12 & 15.4 \\
\hline & Retired & 12 & 15.4 \\
\hline & Student & 3 & 3.8 \\
\hline \multirow[t]{6}{*}{ Reasons for Stay } & Heritage & 50 & 64.1 \\
\hline & Rest and Relaxation & 21 & 26.9 \\
\hline & Visiting relatives and friends & 1 & 1.3 \\
\hline & Business & 1 & 1.3 \\
\hline & Attending a conference, seminar, other form of educations & 1 & 1.3 \\
\hline & Others & 4 & 5.1 \\
\hline \multirow[t]{5}{*}{ Annual Income } & Less than RM36,000 & 10 & 12.8 \\
\hline & RM36,001 to RM60,000 & 17 & 21.8 \\
\hline & RM60,001 to RM 84,000 & 16 & 20.5 \\
\hline & RM84,001 to RM 108,000 & 15 & 19.2 \\
\hline & More than RM 108,000 & 20 & 25.6 \\
\hline \multirow[t]{4}{*}{ Type of Boutique Hotel } & Economy & 1 & 1.3 \\
\hline & Mid-scaled with F\&B & 43 & 55.1 \\
\hline & Mid-scaled without F \&B & 15 & 19.2 \\
\hline & Upscale & 19 & 24.4 \\
\hline
\end{tabular}

\subsection{Measurement Model}

To test the hypotheses, this study used 22 items (see Table 2) adapted from previous literature (e.g. Han \& Back, 2007; Han et al., 2010; Lee et al., 2010), modified accordingly to suit the boutique hotel context. Constructs were measured using a 7-point Likert scale, using 1 for strongly disagree and 7 for strongly agree, with the exception of overall image, which used 1 for very negative and 7 for very positive, and attitude, which used a 7-point semantic differential scale.

Table 2. Sources of measurement scale items

\begin{tabular}{llll}
\hline Variable Measurement & Source & Number of Items & Type of Variable \\
\hline Attitude (ATT) & Han et al. (2010) & 7 & Independent \\
Subjective Norm (SN) & Han et al. (2010) & 3 & Independent \\
Perceived Behavioural Control (PBC) & Han et al. (2010) & 3 & Independent \\
Overall Image (OI) & Lee et al. (2010) & 3 & Independent \\
Customer Satisfaction (CS) & Han and Back (2007) & 3 & Independent \\
Revisit Intention (RI) & Lee et al. (2010) & 3 & Dependent \\
\hline
\end{tabular}


Confirmatory Factor Analysis (CFA) was used to test the two main criteria for goodness of measures, validity and reliability. Reliability tests how consistently an instrument measures the concept it is intended to measure, and validity tests how well an instrument measures the particular concept it is intended to measure (Sekaran \& Bougie, 2010). Validation and reliability were analysed using Smart PLS 2.0 software (Ringle et al., 2005).

\subsubsection{Construct Validity}

Construct validity demonstrates confidence that item measures taken from a sample represent the actual true score in the population (Hair et al., 2013). As argued by Hair et al. (2013), outer loadings above 0.50 as significant and the items should retain. Overall results demonstrate loadings for items above 0.50 and cross loadings below 0.50 . Hence, in this study, it is argued that construct validity is satisfactory.

\subsubsection{Convergent Validity}

Convergent validity is the degree to which multiple items measuring the same concept are in agreement. According to Hair et al. (2013) establishing convergent validity is best achieved using the main loadings, composite reliability (CR) and average variance extracted (AVE). Results from this study showed that the loadings for all items exceeded the recommended value, greater than 0.5 , composite reliability exceeded the recommended value of 0.7 and the AVE was in the range of 0.591-0.888, which is greater than 0.5 as suggested by Hair et al. (2013). Therefore, the overall measurement model of this study demonstrated adequate convergent validity.

\subsubsection{Reliability Testing}

Internal consistency reliability was evaluated using composite reliability values (Hair et al., 2013). The results of reliability test demonstrated that composite reliability CR values $(0.828-0.96)$ exceeded the recommended value of 0.70 suggested by Hair et al. (2013). Hence, it can be concluded that the measurements are reliable.

\subsubsection{Discriminant Validity}

The discriminant validity examines whether items load more strongly on their own constructs in the model. The square root of average variance shared between each construct and its measures should be greater than the variance shared between the construct and other constructs (Fornell \& Larcker, 1981; Hair et al., 2013). Overall results supported that the squared correlations for each construct are less than the square root of average variance extracted by the indicators. Hence, this study demonstrated adequate discriminant validity.

\subsection{Structural Model and Hypotheses Testing}

Next, this study proceeds to test the five hypotheses by employing path analysis, resulting in an $R^{2}$ value of 0.458 that indicates that $45.8 \%$ of the variance in revisit intention can be explained by attitude, subjective norm, perceived behavioural control, overall image and customer satisfaction (refer to Figure 1). In order to examine the results of hypotheses testing, bootstrapping with 5000 samples, the minimum suggested by Hair et al. (2013) was used. Results presented in Table 3 (also see Figures 1 and 2$)$ show that attitude $(\beta=0.362, p<0.01$ ), subjective norm $(\beta=0.144, \mathrm{p}<0.05)$ and customer satisfaction $(\beta=0.356, \mathrm{p}<0.01)$ positively and significantly influence tourist revisit intentions to boutique hotels. Hence, H1, H2 and H5 were supported. However, perceived behavioural control and overall image did not have any significant relationship with tourist revisit intentions to boutique hotels; $\mathrm{H} 3$ and $\mathrm{H} 4$ were not supported.

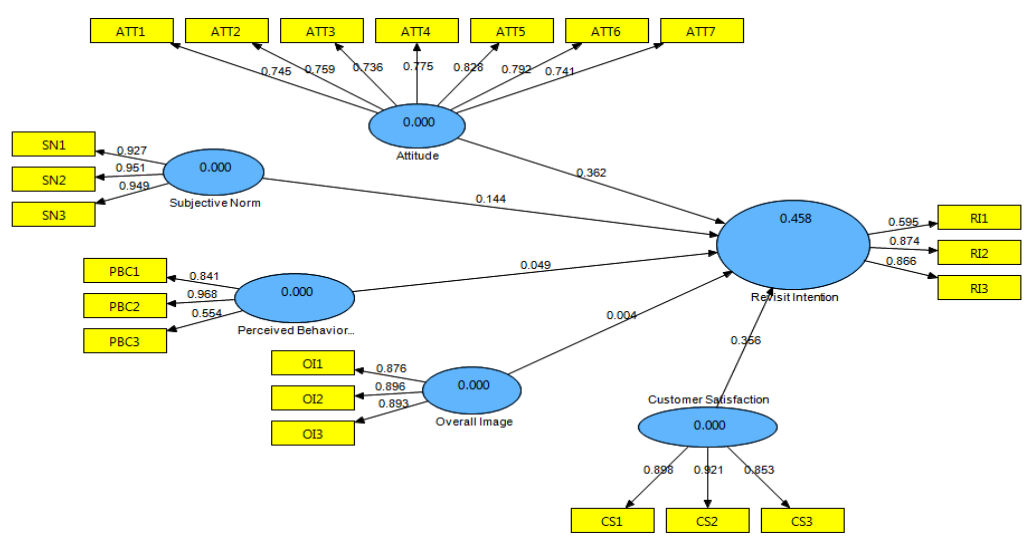

Figure 1. Results of the Path Analysis. $R^{2}$ indicates that $45.8 \%$ of the variance in revisit intention can be explained by attitude, subjective norm, perceived behavioural control, overall image and customer satisfaction 


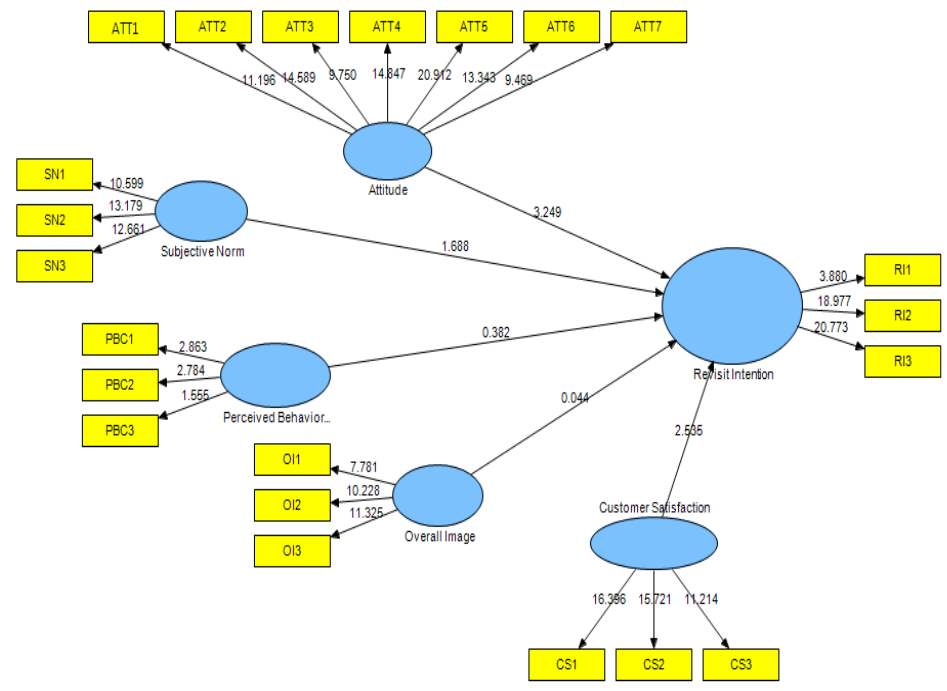

Figure 2. Results of the path coefficient from bootstrapping

Table 3. Hypothesis testing results

\begin{tabular}{|c|c|c|c|c|c|}
\hline Hypothesis & Relationship & $\begin{array}{l}\text { Standard } \\
\text { Beta }\end{array}$ & $\begin{array}{l}\text { Standard } \\
\text { Error }\end{array}$ & $t$-value & Decision \\
\hline H1 & Attitude $\rightarrow$ Revisit Intention & 0.362 & 0.111 & $3.249^{* *}$ & Supported \\
\hline $\mathrm{H} 2$ & Subjective Norm $\rightarrow$ Revisit Intention & 0.144 & 0.085 & $1.688^{*}$ & Supported \\
\hline $\mathrm{H} 3$ & $\begin{array}{l}\text { Perceived Behavioural Control } \\
\rightarrow \text { Revisit Intention }\end{array}$ & 0.049 & 0.129 & 0.382 & $\begin{array}{l}\text { Not } \\
\text { Supported }\end{array}$ \\
\hline $\mathrm{H} 4$ & Overall Image $\rightarrow$ Revisit Intention & 0.004 & 0.092 & 0.044 & $\begin{array}{l}\text { Not } \\
\text { Supported }\end{array}$ \\
\hline H5 & $\begin{array}{l}\text { Customer } \\
\text { Intention }\end{array}$ Satisfaction $\rightarrow$ Revisit & 0.356 & 0.140 & $2.535^{* *}$ & Supported \\
\hline
\end{tabular}

Note: ${ }^{* *} p<0.01(2.33),{ }^{*} p<0.05(1.645)$

\section{Discussion and Conclusion}

The findings of this study support previous research by Ekinci et al. (2008), Han and Kim (2010) and Han et al. (2010) that also suggested attitude has a positive and significant relationship with revisit intention. In this study, attitude has the greatest influence on the proposed relationship $(\beta=0.362, p<0.01)$, which shows that study respondents believe that having a favourable attitude toward a boutique hotel plays a role in their decision making and revisit intention. This implies that a high standard of service delivery is important if hoteliers want customers to enjoy their stay and create favourable attitudes that influence their intention to revisit.

Subjective norm positively and significantly influenced customer revisit intention for boutique hotels in George Town. This result is in line with outcomes from extant empirical studies in the hospitality sector, Han and Kim (2010) and Han et al. (2010), and confirms that visitors to boutique hotels are significantly influenced by the opinions of people important to them, which affects their intention to revisit.

Past research has extensively examined the relationship between customer satisfaction and revisit intention (e.g. Clemens et al., 2011; Han \& Kim, 2010; Huang \& Hsu, 2009; Ryu \& Han, 2010), and the results in this study further confirm that customer satisfaction has a positive and significant relationship on revisit intention. Customers who are satisfied and happy with the service experience provided by a boutique hotel are more likely to associate revisit intention. Hence, these results seem to imply that success of a boutique hotel is inexorably linked to customers' service experience, which is fundamental to customer satisfaction.

Surprisingly, perceived behavioural control is positively but insignificantly related to revisit intention. This finding is inconsistent with previous studies on revisit intention, which found a significant relationship. It also implies that visitors to George Town's boutique hotels perceive that revisiting a hotel has no relationship at all to 
whether they have the resources, time and opportunity when travelling.

Another finding that was inconsistent with previous research was overall image, which is positive but insignificant. This shows that even though the overall image of staying at a boutique hotel could be positive and favourable, it was not a significant factor influencing revisit intention. The authors argue that the respondents in this study might be influenced by others factors, such as the reason for their stay. For example, more than $60 \%$ of the total respondents in this study cited the heritage experience as the reason for their stay at a boutique hotel. As such, external factors, such as heritage experience, which is associated with the location and its historical buildings, has not been explored in this study.

\subsection{Limitations}

We note several limitations with the current study. With a small sample size and low response rate, the findings may not be generalized to the entire population of customers visiting boutique hotels in Malaysia. Therefore, interpretation and generalization of the findings to all boutique hotels in Malaysia must be done with caution. It is suggested that future studies examining customer revisit intention using larger sample size and different sampling method may complement this study.

\subsection{Implications}

The results of this study highlight significant implications for hoteliers. The research findings provide new insights of customers' perceptions (i.e. attitude), which are important for new product development, market segmentation and effective communication strategies. Moreover, for investors in boutique hotels in George Town, these findings deliver customer profiling insights and their intentions to revisit boutique hotels located in the UNESCO world heritage site, which has experienced tremendous growth since 2008. In addition, studies of revisit intention provide tourism bodies and local authorities valuable market information, which helps them develop George Town and maintain its competitive edge as a popular destination in Malaysia. Moreover, by identifying key determinants that appeal to customers or tourists, this study can contribute to the theme in destination marketing under Visit Malaysia 2014.

\section{Acknowledgements}

This study is funded by a short-term research grant (304/PPAMC/6311127) from Universiti Sains Malaysia, Penang, Malaysia.

\section{References}

Aggett, M. (2007). What has influenced growth in the UK's boutique hotel sector? International Journal of Contemporary Hospitality Management, 19(2), 169-177. http://dx.doi.org/10.1108/09596110710729274

Ajzen, I. (1991). The theory of planned behavior. Organizational behavior and human decision processes, 50(2), 179-211. http://dx.doi.org/10.1016/0749-5978(91)90020-T

Bunchua, E., \& Chakpitak, N. (2011). Marketing information and knowledge in boutique hotels: A qualitative study. The International Journal of Knowledge, Culture and Change Management, 10(7), 159-168.

Chin, W. W. (1998). Issues and opinion on structural equation modelling. MIS Quarterly, 22(1), 7-16. Retrieved from http://eds.b.ebscohost.com/ehost/pdfviewer/pdfviewer?sid=9ce4a9e6-13e0-4203-a4ca-40cc4efa801 b\%40sessionmgr112\&vid $=1 \&$ hid $=101$

Chin, W. W. (2000). Partial least squares for researchers: An overview and presentation of recent advances using the PLS approach. Retrieved from http://disc-nt.cba.uh.edu/chin/ icis2000plstalk.pdf

Clemens, M. D., Gan, C., \& Ren, M. (2011). Synthesizing the effects of service quality, value and customer satisfaction on behavioral intention in the motel industry: An empirical analysis. Journal of Hospitality and Tourism Research, 35(4), 530-568. http://dx.doi.org/10.1177/1096348010382239

Ekinci, Y., Dawes, P. L., \& Massey, G. (2008). An extended model of the antecedents and consequences of consumer satisfaction for hospitality services. European Journal of Marketing, 42(1/2), 35-68. http://dx.doi.org/10.1108/03090560810840907

El-Dief, M., \& Font, X. (2010). The determinants of hotels' marketing managers' green marketing behaviour. Journal of Sustainable Tourism, 18(2), 157-174. http://dx.doi.org/10.1080/09669580903464232

Fornell, C., \& Larcker, D. F. (1981). Evaluating structural equation models with unobservable variables and measurement error. Journal of Marketing Research, 18(1), 39-50. http://dx.doi.org/10.2307/3151312

Goh, Y. N. (2014). Customers' Revisit Intention on Penang Boutique Hotel at George Town UNESCO's World 
Heritage Site: A Conceptual Paper, Recent Trends in Social and Behavioral Sciences. Proceedings of the International Congress on Interdisciplinary Behaviour and Social Sciences, 213-216.

Hair, J. F., Hult, G. T. M., Ringle, C. M., \& Sarstedt, M. (2013). A Primer on Partial Least Squares Structural Equation Modelling (PLS-SEM). Thousand Oaks: Sage.

Han, H., \& Back, K. J. (2007). Investigating the effects of consumption emotions on customer satisfaction and repeat visit intentions in the lodging industry. Journal of Hospitality and Leisure Marketing, 15(3), 5-30. http://dx.doi.org/10.1300/J150v15n03_02

Han, H., \& Kim, Y. (2010). An investigation of green hotel customers' decision formation: Developing an extended model of theory of planned behavior. International Journal of Hospitality Management, 29(4), 659-668. http://dx.doi.org/10.1016/j.ijhm.2010.01.001

Han, H., \& Ryu, K. (2007). Moderating role of personal characteristics in forming restaurant customers' behavioral intention: An upscale restaurant settings. Journal of Hospitality and Leisure Marketing, 15(4), 25-54. http://dx.doi.org/10.1300/J150v15n04_03

Han, H., Hsu, L. T., \& Lee, J. S. (2009). Empirical investigation of the roles of attitudes toward green behaviors, overall image, gender and age in hotel customers' eco-friendly decision making process. International Journal of Hospitality Management, 28(4), 519-528. http://dx.doi.org/10.1016/j.ijhm.2009.02.004

Han, H., Hsu, L. T., \& Sheu, C. (2010). Application of the theory of planned behavior to green hotel choice: Testing the effect of environmental friendly activities. Tourism Management, 31(3), 325-334. http://dx.doi.org/10.1016/j.tourman.2009.03.013

Henderson, J. C. (2011). Hip heritage: The boutique hotel business in Singapore. Tourism and Hospitality Research, 11(3), 217-223. http://dx.doi.org/10.1177/1467358411418569

Horner, S., \& Swarbrooke, J. (2005). Leisure marketing: a global perspective. Oxford: Butterworth-Heinemann.

Huang, S. S., \& Hsu, C. H. C. (2009). Effects of travel motivation, past experience, perceived constraint and attitude on revisit intention. Journal of Travel Research, 48(1), 29-44. http://dx.doi.org/10.1177/00472875 08328793

Kim, Y., \& Han, H. (2010). Intention to pay conventional hotel prices at a green hotel-a modification of the theory of planned behaviour. Journal of Sustainable Tourism, 18(8), 997-1014. http://dx.doi.org/10.1080 /09669582.2010.490300

Lee, J. S., Hsu, L. T., Han, H., \& Kim, Y. (2010). Understanding how consumers view green hotels: How a hotel's green image can influence behavioral intentions. Journal of Sustainable Tourism, 18(7), 901-914. http://dx.doi.org/10.1080/09669581003777747

Lim, W. M., \& Endean, M. (2009). Elucidating the aesthetic and operational characteristics of UK boutique hotels. International Journal of Contemporary Hospitality Management, 21(1), 38-51. http://dx.doi.org/10.1 108/09596110910930179

Lwin, M., \& Phau, I. (2013). Effective advertising appeals for websites of small boutique hotels. Journal of Research in Interactive Marketing, 7(1), 18-32. http://dx.doi.org/10.1108/17505931311316725

Malaysia Airports Holdings Bhd. (2013). Passengers movements 2013. Retrieved July 8, 2014, from http://ir.chartnexus.com/malaysiaairports/doc/statistics/MAHB\%20Statistic\%202013.pdf

Mcintosh, A. J., \& Siggs, A. (2005). An exploration of the experiential nature of boutique accommodation. Journal of Travel Research, 44(1), 74-81. http://dx.doi.org/10.1177/0047287505276593

Oliver, R. L. (1997). Satisfaction: A behavioural perspective on the consumer. McGraw-Hill, New York.

Penang Tourism Net Website. Retrieved January 21, 2013, from http://www.tourismpenang.net.my/index.php/ George-Town/boutique-hotels-in-george-town

Ringle, C. M., Wende, S., \& Will, S. (2005). Smart PLS 2.0 (M3) Beta. Hamburg. Retrieved from http://smartpls.de

Ryu, K., \& Han, H. (2010). Influence of the quality of food, service and physical environment on customer satisfaction and behavioral intention in quick casual restaurants: Moderating role of perceived price. Journal of Hospitality and Tourism Research, 34(3), 310-329. http://dx.doi.org/10.1177/1096348009350624

Sekaran, U., \& Bougie, R. (2010). Research methods for business: A skill-building approach. UK: Wiley. 
Sparks, B. (2007). Planning a wine tourism vacation? Factors that help to predict tourist behavioural intentions. Tourism Management, 28(5), 1180-1192. http://dx.doi.org/10.1016/j.tourman.2006.11.003

Su, L. J., \& Hsu, M. K. (2013). Service fairness, consumption emotions, satisfaction and behavioural intentions: The experience of Chinese heritage tourists. Journal of Travel and Tourism Marketing, 30(8), 786-805. http://dx.doi.org/10.1080/10548408.2013.835228

The Star Property Online. (2014). New hotel launches expected to boost tourism in Penang. Retrieved May 9 , 2014, from http://www.starproperty.my/index.php/articles/property-news/new-hotel-launches-expectedto-boost-tourism-in-penang-2/

Victorino, L., Verma, R., Plaschka, G., \& Dev, C. (2005). Service innovation and customer choices in the hospitality industry. Managing Service Quality, 15(6), 555-576. http://dx.doi.org/10.1108/096045205 10634023

\section{Copyrights}

Copyright for this article is retained by the author(s), with first publication rights granted to the journal.

This is an open-access article distributed under the terms and conditions of the Creative Commons Attribution license (http://creativecommons.org/licenses/by/3.0/). 